\title{
An Ethical and Legal Framework for Physicians as Surrogate Decision- Makers for Their Patients
}

\author{
Philip M. Rosoff and Kelly M. Leong
}

$\mathrm{O}$ ver the last century, and especially since the publication of the Belmont Report in 1978, respect for persons, as exemplified by respect for autonomous decision-making, has become a central tenet in the practice of medicine. ${ }^{1}$ The authority of cognitively competent adults to make their own healthcare decisions is enshrined in both law and practice in most advanced industrialized nations. The right to consent to or to refuse medical interventions is virtually absolute, but is contingent on the provision of materially relevant information about the benefits and burdens or risks of the proposed treatment as well as the freedom from coercion by others, especially healthcare personnel. This power also extends to the kinds, amounts and details of the proposed intervention, including the option to decline to hear anything, if one so chooses, assuming that this is a rational choice. This respect transfers to other competent individuals who are authorized as surrogates to decide for those who have temporarily or permanently lost the capacity to make their own healthcare decisions.

Surrogate decision-making is well-established in Western healthcare systems. It is likely that most people will serve as and be served by a surrogate at some

Philip M. Rosoff, M.D., M.A., received his medical degree from Case Western Reserve University School of Medicine in 1978 and his Masters in Philosophy from Duke University in 2008. He is a Professor of Pediatrics and Medicine at Duke University Medical Center and a Scholar in the Trent Center for Bioethics, Humanities and History of Medicine at Duke University School of Medicine in Durham, NC. Kelly M. Leong, J.D., received her Juris Doctor from Nerw England School of Law in 2007 and her Masters of Library Science from University of North Carolina at Chapel Hill in 2011. She was a Reference Librarian and Lecturing Fellow at Duke School of Law, Duke University, Durham, NC and is now at UCLA School of Law in Los Angeles, CA. point in their lives. Most surrogates are such by default as, for example, they are parents, an adult child, or another relative or friend of the patient. However, patients who are "unbefriended" may have a surrogate appointed by a court. ${ }^{2}$ As a corollary extension of personal autonomy of this type, individuals may exercise their freedom of choice to appoint another (presumably competent) adult to act in their stead should they temporarily or permanently lose their capacity to make healthcare decisions. Ordinarily, this is accomplished by the completion of a durable healthcare power of attorney document, and is often accompanied by an advance directive in which the patient's contingent wishes are described.

Much is required of surrogates including the kind and quality of the decisions they are asked to make. In the U.S. and most of Europe, surrogates are expected to hew to either a substituted judgment or best interest standard in forming their decisions; the former is preferred because it provides the optimal opportunity to represent the patient's own wishes. ${ }^{3}$ Ideally, patients would discuss, in advance, what they would wish to be done in hypothetical situations in which their decision-making capacity has been lost and a surrogate is needed. Likewise, they would gauge in advance the ability of their chosen surrogate(s) to carry out their wishes. This might include ex ante evaluations of the adequacy of the surrogate's decision-making abilities, her aptness to faithfully represent the patient's previously expressed desires or what he might have wanted, and, if necessary, the best interests of the patient as the surrogate is most able to appreciate them drawing upon her knowledge of his life. Whether these evaluations are undertaken or not, however, the power of a competent person to appoint whomever she wishes is generally unquestioned and carries both legal and moral authority. 
Surrogates are also presumed to be making decisions in a manner in which any explicit or implicit conflicts of interest would not interfere with the quality or content of the decision. ${ }^{4}$ For example, the care of patients with life-threatening disorders can be both emotionally taxing and financially draining, and this may influence decisions to terminate life support. Alternatively, surrogates can stand to gain when the person for whom they are making decisions continues receiving care such as an instance in which the patient and her insurance or disability income is the is accurate, surrogates (and patients) may not hear or understand what they have been told. ${ }^{6}$

The increasing fragmentation of healthcare in the US has often led to an erosion of the traditional doctor-patient relationship. Indeed, many patients either switch primary care doctors frequently (due to shifting insurance provider networks) or actually do not have a primary provider at all due to lack of insurance, underinsurance, or the increasing shortage of primary care providers. ${ }^{7}$ Despite these trends, patients frequently can and do develop deep and trusting rela-

The deep and trusting relationships between patients and their doctors may

lead patients to wish to designate their doctor as their surrogate. This might

occur in situations where the patient does not have a family member available

to take on this role, or more likely, when the degree of confidence in the physician is such to warrant such an action. It is not unreasonable to assume that patients who wish their physicians to be their surrogate decision-makers would trust them to make appropriate decisions in their stead. Presumably, this would be based upon their belief that their doctor understood what they themselves believed about their health or medical condition(s), their goals and trajectories of care, and what they would decide were they able to do so. The fact that there is often a lack of concordance between what the patient believes and desires, and what the doctor thinks the patient believes and desires, emphasizes that open honest bilateral communication between the two serves to enhance the level of true understanding.

sole source of monetary support for the surrogate. Both of these situations illustrate the challenges of surrogacy as well as those faced by healthcare workers in evaluating the quality of surrogate motivations and decisions.

The overwhelming majority of surrogates are usually either relatives or friends of the patient. Occasionally, physicians question the wisdom of decisions made by surrogates (and patients) in situations in which there is a difference of opinion about the appropriate course of action to take. Doctors may believe that their superior knowledge and depth and breadth of clinical experience bestow a greater ability to discern the best course of action based upon their prognoses for patient outcomes. However, research has demonstrated that physicians' skill at prognostication for individual patients is less than desired, even if it is regularly expressed as certainty. ${ }^{5}$ And even when it tionships with their doctors. Such relationships are consistent with the covenant of trust between a physician and her patient, a central tenet of medicine as a profession of caring and healing. ${ }^{8}$

The deep and trusting relationships between patients and their doctors may lead patients to wish to designate their doctor as their surrogate. This might occur in situations where the patient does not have a family member available to take on this role, or more likely, when the degree of confidence in the physician is such to warrant such an action. It is not unreasonable to assume that patients who wish their physicians to be their surrogate decision-makers would trust them to make appropriate decisions in their stead. Presumably, this would be based upon their belief that their doctor understood what they themselves believed about their health or medical condition(s), their goals and trajectories of care, and what they would decide were they able to do so. The fact that there is often a 
lack of concordance between what the patient believes and desires, and what the doctor thinks the patient believes and desires, emphasizes that open honest bilateral communication between the two serves to enhance the level of true understanding. ${ }^{9}$

Most states have laws or regulations prohibiting physicians from serving as a surrogate for their own patients, presumably due to apprehension about a conflict of interest (see Table 1). This indicates that these states have concerns that permitting such a relationship between a doctor and his patient would potentially expose the latter to some harm from which patients should be shielded. However, several authors have suggested that this concern is only theoretical or disproportionate to the actual risk for harm to patients and that it is entirely reasonable that competent patients be permitted the opportunity to name their doctors as their healthcare proxies. ${ }^{10}$ They argue that it demonstrates a respect for patient autonomy to allow them the power to decide who best can represent their interests when they can no longer speak for themselves. We partially agree with these previous analyses. However, we do have concerns that there are aspects of this relationship between physician and patient that have not been explored. We write to add clinical, legal, and ethical context to the understanding of this problem and to propose procedures that minimize the risk of harm to competent adults who choose their physician as their healthcare proxy. It is likely that a rapidly aging population with increasing chronic health conditions will only enhance the frequency with which this choice is either made or considered, and hence further and more careful examination is warranted. ${ }^{11}$ In this paper we consider only physicians acting as surrogate decision-makers for their patients. We realize that many people form close trusting relationships with other healthcare providers (such as nurses or advanced practice providers), and it is likely this will become even more common as these individuals supplant many primary care duties that have been associated with doctors in the past. Most of the points of our analysis and recommendations could easily apply to these professionals. It is also pertinent to note that many of the state laws that regulate physicians as surrogates do so as well for nurses, physician assistants, and others in similar roles (see Table 1).

\section{Types of Risks}

Physicians have traditionally adhered to a professional ethical standard to serve the interests of their patients above all else, albeit with certain caveats such as when what they and their patient perceive as the latter's best interest conflicts with requirements of the law (such as public health reporting, for example). In many instances, physicians also obey a much less strict and codified mandate to be responsible custodians of society's resources. ${ }^{12}$ In the United States, this is perhaps best observed in the allocation of solid organs for transplantation where physicians are expected to balance their fiduciary duties to their patients with their stewardship of a critically scarce resource. ${ }^{13}$ These dual and sometimes competing or conflicting obligations can produce strain in the patient doctor relationship. In the transplant realm, this may be partially relieved by reliance on established and "impersonal" illness scoring systems such as the MELD for livers and the LAS for lungs that give ordinal rank to patients awaiting organ(s) based upon consensus numerical classifications of illness severity. ${ }^{14}$ Of course, there are other forms of conflicts of interest between the concerns and needs of patients and their physicians, the most notable being financial, wherein the latter may have a vested involvement with healthcare decisions..$^{15}$

Consider the following case:

Ms. J. Y. is an 83-year-old woman who was admitted to the hospital with delirium, dehydration, a urinary tract infection and deep bedsores on her buttocks. She has suffered from mild dementia for at least 6 years. She also has reasonably well-controlled Type 2 diabetes, hypertension, and coronary artery disease. She had a mild stroke 4 years prior to admission and has a residual moderately dense right-sided hemiparesis (weakness). She has lived at a local nursing home for the past 8 years and before that she lived alone. She has two adult children and a number of grandchildren; they live in another state and she has not seen or communicated with them for many years. Several years prior to entering the nursing home, she asked a friend to be her surrogate decision-maker and completed a durable health care power of attorney (HCPOA) form to that effect. On this same form she listed her long-time primary care doctor as her secondary health care proxy; she informed him of her decision and he did not object. She did not have an additional written advance directive. At the hospital, she was resuscitated with fluids and treated with antibiotics. Her acute delirium gradually cleared, but it became clear that she lacked decision-making capacity. However, her physical condition deteriorated and she went into renal failure. When she was initially transferred to the hospital, the nursing home sent along some paperwork, including the HCPOA form. The hospital attempted to contact her friend, but discovered that she had died 
three years earlier. Thus, her family doctor was her surrogate decision-maker. They contacted him for his advice on what to do.

Is it reasonable that the physician-surrogate fulfill his role and can he do so faithfully and responsibly? Are there unreasonable risks to patients that suggest that there should be restrictions on the power of a competent patient to name whoever she wants - including her doctor - to act as her healthcare proxy? What statutory or professional procedures might be implemented or employed to minimize these risks so that the patient's autonomy and choice are preserved?

In the main, the major risk that has raised questions about physicians as surrogate decision-makers for their own patients has been whether they will be able to make decisions in a way that mimics - to the extent possible - those that would be made by the patient herself without significant interference from other loyalties, duties and obligations - both professional and personal - that they may have. Presumably, this would be similar to, but different from, the substituted judgment norm that is ideally employed by other surrogates. However, unless the physician has had extensive discussions with her patient about what she would want in various sets of circumstances, she must adhere to some form of individual or universal benchmark of best interests. This is obviously a very high standard and one that we suspect most surrogates might fail, at least in some way. Nevertheless, the power invested in the healthcare proxy is very broad and, while their decisions may be questioned, they are rarely refused. Indeed, when challenged legally, courts have been reluctant to relieve surrogates (most often relatives of the patient) of their decision-making authority on the view that the people who know the patient well are best positioned to understand what they would have wanted for themselves, in comparison to healthcare providers whose knowledge of the patient and her values, goals, and preferences may often be relatively superficial. ${ }^{16}$ Physicians are not aided in their effort by their tendency to use medical arguments to buttress their case whereas family members (for example) tend to argue from their knowledge or understanding of what they believed the patient held to be important in her life.

The closest similar circumstance in which doctors are permitted to make relatively unfettered decisions for their patients is in certain jurisdictions when the patient is unbefriended, meaning that he lacks an advance directive or surrogate as well as the capacity for autonomous decision-making. In a number of states where this specific situation is addressed by statute, attending physicians may act as decision- makers until a guardian can be appointed by a court (see Table 1). For example, in North Carolina doctors are authorized to make end-of-life decisions for unbefriended patients without seeking approval of a court as long as "reasonable" efforts have been made to locate someone who could otherwise act as a surrogate (such as a relative or friend). ${ }^{17}$ Under these conditions, the physician is likely making a judgment about the quality of life and the prognosis of the patient given the gravity of the clinical state. However, there is nothing in this law (or others like it) that would prevent a doctor from withdrawing life support from a patient who has a very small, but real, chance of survival but whose style of life (homeless, a substance abuser, etc.) was offensive to the physician. Or, the doctor could be pressured by the hospital (for example) to limit or even stop interventions when the patient is uninsured or underinsured in a strategy to limit unreimbursable costs. Hence, personal or institutional bias could conflict with what may be the patient's best interests (in remaining alive). ${ }^{18}$

Therefore, we can ask the question whether a patient's physician who is named as a proxy, presumably because the patient believes she can best carry out her wishes, can do so with the degree of fidelity required by this position. Would the doctor's other commitments - to the medical profession, any financial obligations that could conflict with this responsibility, to his place of employment, etc. - inhibit the faithful fulfilling of the duties of surrogacy? And are these possible conflicts any more troubling than those often held by the more common surrogate such as a spouse, adult child or friend? While by no means universal, a majority of states seem to think they are, as they place barriers - including complete prohibition - on physicians serving in this role (see Table 1). State restrictions of doctors serving as surrogates range from "A physician or health care provider who is directly involved in your health care may not serve as your health care agent" to "Neither the treating health care provider,...nor an employee of the treating health care provider, nor an employee, owner, director or officer of a facility described [in] subsection (a)(2) in K.S.A. 58-629 may be designated as the agent to make health care decisions under a durable power of attorney for health care decisions...." ${ }^{19}$ Most of the state prohibitions restricting physicians serving as healthcare proxies seem to be concerned with the possibility of a financial conflict of interest on the part of the physician, as they often include references to employees of the patient's physician or the facility where the doctor works as also being proscribed. There are also states that specifically reference long-term care establish- 
ments such as nursing homes (see Table 1). Presumably, the concern is that physicians may utilize a

"captive" group of patients for referral to for-profit entities in which they hold an equity position. ${ }^{20}$ Since these kinds of activities go on with patients who are competent, there is little reason to believe that physicians would restrict these schemes if they became surrogates. There is also little question that sick people are vulnerable to exploitation, but the exploitation of this vulnerability is not restricted to doctors, as relatives may also take financial advantage of their ill kin. their own healthcare proxies. However, this is not an unfettered right, and it should be tempered with reasonable constraints to diminish the opportunities for abuse. We can safely assume that the greatest concern reflected in statutes prohibiting physicians (or other healthcare providers or workers associated with a patient's care) from serving as healthcare proxies is the potential risk for taking advantage of the patient for the proxy's gain. While this risk may be more hypothetical than real, there certainly is ample evidence demonstrating that physicians do recommend or per-

We believe that it is of fundamental importance to respect the free will and informed decisions of capacitated individuals and thus their prerogative to choose their own healthcare proxies. However, this is not an unfettered right, and it should be tempered with reasonable constraints to diminish the opportunities for abuse. We can safely assume that the greatest concern reflected in statutes prohibiting physicians (or other healthcare providers or workers associated with a patient's care) from serving as healthcare proxies is the potential risk for taking advantage of the patient for the proxy's gain.

However, physicians who grossly abuse the doctorpatient relationship for such overt personal gain are a relative minority. The greater concern might be with doctors whose income is wholly or partially dependent upon prescribing certain types of medications, such as private practice oncologists who generate more profit by using brand-name, expensive chemotherapy rather than cheaper generics, or cardiologists who choose costly interventions when medical pharmacologic therapy might be equally as effective. ${ }^{21}$ It may be assumed that these physicians might be tempted to exploit the position of power conferred by surrogacy to their financial advantage. However, considering the fact that most patients take their doctor's advice seriously, it is unlikely that the difference between what might be recommended for competent patients versus the incompetent is very significant. Nevertheless, there may be approaches to this possible risk to both minimize it even further (see below) and expand the freedom of patient choice in those jurisdictions that currently restrict it.

\section{A Procedural Approach to Govern Doctors as Healthcare Proxies}

We believe that it is of fundamental importance to respect the free will and informed decisions of capacitated individuals and thus their prerogative to choose suade or utilize interventions and treatments that can be to their financial benefit (see above). It is worth noting in this context that states also restrict the initiation and maintenance of other personal associations between patients and their physician's that may be liable to abuse or exploitation of vulnerable patients, such as romantic and sexual relationships.

Hence, we propose the following steps that we believe could minimize this risk (see Table 2). We should emphasize that these recommendations apply only to those doctors who are directly asked to become proxies by the patient, and not those who may be named without their knowledge or consent in advance directive or durable healthcare power-ofattorney documents. In that situation, when the physician discovers her role, she may decline to fulfill it unless the patient would otherwise be unbefriended in which case the doctor might be statutorily empowered to make decisions anyway (in end-of-life scenarios, although this varies from state to state) or could refer the case to the local courts for appointment of a guardian. We should also clarify that we direct these statements only to situations in which a physician is acting as a proxy for her own patient, and not a relative or someone with whom she does (or did not have) a therapeutic relationship. We present 6 main concerns that justify regulating situations when a patient 
asks her physician to be her proxy. We also counter these concerns with suggested remedies. At the outset we should state that our goal in describing these six domains and our suggestions for reasonable remedies attempts to balance the liberty interests of cognitively capacitated adults to make free choices with those of the state in minimizing the risks to themselves in the context of situations that can be fraught with emotion and the risk of manipulation. Hence, we would foresee that these safeguards would enable an individual to choose his physician as his surrogate decision-maker even when there may be family members willing and able to perform this function, the lack of an advance directive, etc.

\section{Established Relationships}

It is conceivable that physicians who barely know a patient (although the patient may believe otherwise) may be asked to be a surrogate. At a minimum, we believe that some reasonable knowledge about whom the patient is as a person (and not simply as a clinical entity) is mandatory. As a reflection of such knowledge, we suggest that time may be a reasonable barometer. Physicians who are asked to become healthcare proxies, especially if they are asked to do so when there are relatives or good friends of the patient who could also potentially fulfill this role, should have an established professional relationship with the patient for at least one year. We fully realize that this may be a very high bar in a fragmented healthcare system that does not require that patients have primary care providers who are capable of initiating and maintaining a long-term relationship. Nevertheless, we believe that this is a reasonable prerequisite as it represents sufficient time (and presumed clinical encounters) for some practicable form of close relationship to be established. This precondition should enhance the likelihood that both parties know each other sufficiently well to engage in the sorts of discussions important to effective advance care planning. Doctors who are considering whether to accept a patient request to be their health-care power of attorney should encourage the patient to notify his or her friends and relatives about this fact so as to avoid any future misunderstanding when the patient requires a surrogate decision-maker. Finally, it should be clear that the requirement of length of time of a relationship is an imperfect proxy for "the real thing." It is certainly true that many patients (especially healthy ones) may have very few encounters with their doctor over the length of a year. But even if we had suggested that there should be some minimal number of visits involving face-to-face interactions, we would still be left with a numerical account of what we are really interested in: a suitable representation of a personal connection that is sufficiently close to offer minimally acceptable assurance of the doctor being able to credibly perform this role.

\section{Detailed Discussions}

Many patients do not discuss their preferences with their surrogates. However, when they do, their wishes are more likely to be carried out. ${ }^{22}$ Physicians are frequently no more skilled at divining what their patients want than close relatives. ${ }^{23}$ Therefore, in addition to the time requirement (above), there should be evidence of substantive conversations between the patient and her physician about this topic. A careful and detailed discussion of the patient's values and interests should occur before the doctor can accept the role as proxy. The content of this discussion(s) should be carefully documented in the medical record. This is especially germane since data shows that doctors might make different recommendations to patients than they would for themselves in a similar clinical situation. ${ }^{24}$ Aside from other considerations, the importance of pre-morbid conversations accords with physicians' general belief in the substituted judgment standard for surrogate decision-making. ${ }^{25}$ While this is the expected norm, without conversations of substantive content relevant to future care planning, the more general "best interests" rule might be applicable. Unfortunately, these sorts of discussions take time, a commodity often in short supply for busy doctors. Furthermore, physicians are often not especially skilled in eliciting patients' values and goals. ${ }^{26}$ At the same time, an added precaution might be to include a witness or other individual able to impartially assist the patient create an advance directive to document at least some of the patient's considered wishes. While the value of such documents has come under significant criticism of late, they do possess some usefulness even if they have not fulfilled their initial promise. ${ }^{27}$

The United States is a very religious country, and at the same time, a very religiously heterogeneous nation. ${ }^{28}$ Thus, many patients and their physicians many not share the same religious affiliation, obligations or depth of spirituality and hence views on subjects of importance to medical decision-making. ${ }^{29}$ Therefore, it would be important for physicians to discuss the influence of the patient's religious beliefs and how they might influence the kinds of decisions that could be made once the patient is no longer capable of making her own choices. In addition, the physician in the position of determining whether he can be a responsible surrogate must examine his own beliefs and whether he can carry out those directives of the patient that may conflict with his own deeply held moral and spiritual commitments. If not, then 
he must decline to serve as a surrogate. Finally, we would recommend that these discussions be revisited at least annually (or more frequently, if the patient experiences a significant change in her medical and/or social circumstances) as conditions, views, beliefs and expectations may alter with time and may influence the quality and kinds of preferences one may have.

\section{Conflicts of Interest}

The physician should reveal any real or potential conflicts of interest to the patient before accepting a role as a surrogate decision-maker. Most often, these will be relational or financial in nature. While some authors have suggested that public knowledge of con- consequences. Thus, even the appearance of a conflict that could jeopardize the legitimacy with which an act is perceived should be reviewed and scrutinized very carefully.

Finally, it may be advisable to require that a dispassionate observer (or participant) be involved for decisions of consequence being made by the doctor-surrogate on behalf of his patient-"ward" perhaps to serve as a neutral party to plausibly or suitably scrutinize and evaluate the best interests of the patient in this context. However, from a practical standpoint, it may be difficult to find people to fulfill this role who themselves did not have some sort of conflict (employee of the hospital or clinic, etc.).

\section{It may be advisable to require that a dispassionate observer (or participant) be involved for decisions of consequence being made by the doctor-surrogate on behalf of his patient-"ward" perhaps to serve as a neutral party to plausibly or suitably scrutinize and evaluate the best interests of the patient in this context. However, from a practical standpoint, it may be difficult to find people to fulfill this role who themselves did not have some sort of conflict (employee of the hospital or clinic, etc.).}

flicts is sufficient to counter their possible corrosive effects on decision-making, others have disagreed and the best course of action is still debatable. ${ }^{30}$ If the position is taken that maintaining individual autonomy and personal power over the delegation of decisional authority is paramount, then full disclosure of conflicts should be satisfactory. Of course, this places the burden of honest and complete declarations with the doctor, and entrusts to him the responsibility of what we would hope to be a reasonably liberal interpretation of what should be revealed. In addition, this also assigns to the physician the responsibility to educate herself sufficiently to capably identify what may be reasonably be understood as possible conflicts. Disclosures should be documented in the patient's medical record and updated as needed. Physicians' careers also undergo change with time and previously nonexistent conflicts may arise after the initial disclosure; if any meet the benchmark of being irresolvable, then the already established proxy-surrogate relationship should be dissolved. The physician should also inquire as to whether he or his institution or a charity he favors, etc., is a beneficiary in the patient's will; if so, he must decline to be the healthcare proxy. Importantly, healthcare proxies are frequently called upon to make life or death decisions resulting in irrevocable

\section{Determination of Decision-Making Capacity}

Healthcare proxies are "activated" when the patient loses temporary or permanent capacity to make decisions for herself. Ordinarily, one's physician (or other physicians) declares when this occurs, unless it is obvious, such as when a patient is under general anaesthesia and a critical decision by a proxy is needed. It seems reasonable that when the physician is the proxy, she should not also be the person who makes the declaration of loss of healthcare decision-making capacity. This could remove both the appearance and the dual possibility that the doctor-surrogate could prematurely - with either benign or malicious intent declare someone to lack capacity (and hence activate the surrogacy role). Therefore, it would be sensible to have in place an arrangement for other trusted physicians who separately do not hold a conflict of interest with either the doctor-proxy (such as a commercial partnership or relationship) or the patient to make this determination when the patient's doctor believes a threshold of cognitive functioning has been lost.

\section{End-of-Life Decisions}

End-of-life decisions may result in consequences that are irreversible (i.e., withdrawal or withholding of life support) and hence should be open to careful 
and thoughtful scrutiny. This is especially true when the physician is the healthcare proxy and thus responsible for making these kinds of decisions. White and his colleagues have suggested that end-of-life decisions for unbefriended patients that are entrusted to doctors (such as in the intensive care unit) should be reviewed prior to their implementation to obtain consensus as to the reasonableness of the approach and to avoid unilateral, arbitrary actions. ${ }^{31}$ It seems sensible that this approach could be discussed with the patient at the time of the initial conversation about desires and wishes. It is certainly plausible that such a strategy could engender even more trust in the doctor's ability to carry out the patient's wishes if the latter was assured that the physician would not make precipitous decisions and would consult colleagues prior to executing any irrevocable course of action. There are many other kinds of therapeutic decisions that may not be as irrevocably consequential as those involving care and the end of life, but could have significant impact on both the quality and quantity of life for patients. These, too, may benefit from this sort of secondary review prior to implementation (assuming that time permits). While we would not wish to draw a sharp distinction between what kinds of clinical situations should qualify for such scrutiny (and those that would not), it would be worthwhile giving this more careful thought. Perhaps the physician assuming the role of surrogate could map out plausible scenarios with the (currently) cognitively capacitated patient of what types of decisions should trigger a "second opinion."

\section{Clinical Research}

Patients are not infrequently offered the opportunity to enroll in clinical trials. For studies such as those examining therapies for dementia, the participation of patients who lack decision-making capacity may be mandatory, and hence require the consent of their surrogates. There would be an added layer of complexity when the surrogate is also the patient's doctor. We believe that it would be inappropriate for a physician as proxy to enroll the patient who is in her charge in a research study as a subject, unless there were overly compelling reasons to do so. Our justification for this view is that it would be expanding the customary role of an authorized surrogate to consider the individual for whom one is acting as proxy as both a patient (a clinical matter) and as a subject in an experiment. While it is not uncommon for physicians to occupy the dual positions as caregiver, whose primary duty is the welfare and best interests of her patient, and that of clinical investigator, whose primary duty is to the integrity of the study and its data gathering mission, of course tempered with due concern for the welfare of subjects, taking on an additional position as surrogate seems exceptional and an unnecessary conflict. Impartial advocacy on behalf of patients and a clinical trial of which she is also principal (or participatory) investigator demands too much hairsplitting of responsibilities.

There are certainly medically worthwhile and scientifically challenging clinical trials from which either society or the patient himself might benefit. In some ways this situation bears some resemblance to the role that parents have when considering having their children become research subjects. However, parents have a significantly closer emotional and entailing relationship with their children than does a physician who has accepted the position of healthcare proxy for one of his patients. Another appealing approach would be to seek the opinion of an outside party (such as an ethics committee) about the suitability of enrolling the patient as a subject in a given study. Perhaps criteria similar to those governing much research in minors should prevail in the unusual, but certainly plausible situation: only clearly therapeutic Phase 3 trials and/or those involving minimal risk would be acceptable. ${ }^{32}$ Moreover, the physician who is the proxy should not herself be the principal investigator or co-investigator of the study to avoid a conflict of interest.

\section{Conclusion}

Cognitively able and legally autonomous patients are best situated to know what serves their interests, irrespective of the domain: financial, social or medical. In addition, the Western tradition of individual liberty endows persons with significant authority to guide the direction of their own lives with limited interference from others. In the history of the practice of clinical medicine, this virtue has only relatively recently been honored as much as it has in other areas. The power to dictate what does or does not happen to one's body can be transferred to a surrogate to act in one's stead when one no longer retains the ability to perform this function. For the most part, surrogates command the same authoritative decision-making power as patients. It is assumed that patients will specifically choose people they trust to carry out their wishes or, if they fail to designate someone, that close relatives or friends can fulfill this function better than someone who does not know the patient. Occasionally, patients want to choose their doctors as their surrogates, and this raises some practical and ethical questions. Indeed, most states are sufficiently concerned about the potential abuse of this unique position for doctors that they have prohibited it by statute. However, hard evidence for outright 
abuse or exploitation is lacking or apocryphal in those jurisdictions where it is permitted. The question then remains whether barring the availability of this option for patients represents an unwarranted restriction on their liberty of choice.

The few authors who have expressed their opinions on this matter (previously cited) have suggested that scant limitations be placed on the freedom of competent adults to choose whomever they wish to represent their interests when they are no longer able to do so themselves. For the most part, we agree. However, we also are sensitive to the fact that the doctor-patient relationship is a unique one, even when compared to those relationships that more commonly form the basis on which patients choose their surrogates (or more commonly have them designated by default). The distinctiveness of the relationship with its asymmetry in knowledge, power, and vulnerability makes it especially sensitive to possible exploitation. To the extent that it is possible via either regulation or statute or enforceable professional standards, to minimize the opportunities or chances of unwise or imprudent choices of surrogates then that should be a not unreasonable goal of such activities. While a fair rejoinder might be that patients make ill-considered decisions for themselves all the time and delegate decisional authority to others who seemingly are poorly suited to the task, there is a unique aspect to awarding such power to one's physician who already enjoys exceptional influence and control over the therapeutic encounter under ordinary circumstances. It seems not unreasonable to attempt to ensure that vulnerable patients be somewhat protected from the worst consequences of the injudicious granting of decisionmaking power to their doctors.

There are other domains in which states believe that vulnerable individuals deserve some protections such as children undergoing adoption. People wishing to adopt a child must undergo reasonably intense scrutiny to demonstrate their ability (including financial) to safely raise a child. Presumably, this is believed to be necessary to minimize the chances for harm to the prospective adoptee and maximize (to the extent possible) the opportunities for the child to have a safe and nurturing home, as the state has a separate interest in his or her well-being. However, similar action by the government is thought to be too intrusive for natural-borne babies, and there are relatively few limitations on the freedom of biological child-bearing. While some states have passed laws to "protect" the fetus from "abuse" by the pregnant woman (such as maternal drug use), in general child safety laws do not become effective until after the child is born and then only when there is reason to believe the child may be in danger. ${ }^{33}$ Similarly, the government leaves the active choice of surrogate decision-makers to the patient. When a surrogate is not chosen by the patient, most jurisdictions assume that close relatives or friends can perform this function without prior scrutiny, but the majority of states single out personal physicians as a special case.

We believe that the regulations we have suggested neither place an undue burden on the physician or her patient or are unreasonable. Indeed, several of them are already considered "best practice" in advance care planning. They recognize that many states have concerns about the potential for abuse if the doctorpatient relationship is transformed from one in which shared decision-making is the ideal to one in which the physician must integrate both his scientific-medical knowledge and the singular power to effect an outcome due to his position as surrogate. ${ }^{34}$ These proposed requirements would permit the patient to make a considered and thoughtful determination that her doctor is best placed (in her opinion) to ensure her welfare when she can no longer do so herself, subject only to conditions that would enhance the prospects that her wishes would be realized in a responsible and respectful manner.

One more observation deserves careful consideration. The U.S. Supreme Court ruled in 1889 that the states have the right and power to regulate some aspects of medical practice in order to fulfill their duty to protect the welfare of their citizens..$^{35}$ That case concerned the interest of the state to mandate that physicians have certain educational qualifications (and a license) in order to practice medicine. Since then the regulatory apparatus that has developed to supervise medical practice has been codified by legislative statute throughout the country. Indeed, there is little debate about whether states should be able to authorize and restrict the professional activities of physicians. When a doctor assumes the position and responsibility of acting as a healthcare proxy for one of his own patients, this alters the established therapeutic relationship to one in which the patient no longer possesses the free will (after she loses capacity) to refuse his advice. Her fate is at the mercy of someone else. Of course, that is also true for other surrogates, such as close relatives or friends, but the patient's physician holds a unique place in this association, one that was initiated and built upon different kinds of social bonds. While we should be loath to prevent patients from choosing their trusted physicians as their proxies, we should also recognize that the distinctive and peculiar manner in which such choosing arises deserves special scrutiny and care, and it is reasonable for states to mandate some control over the 
Table

Summary of State Laws Governing Healthcare Providers Acting as Healthcare Proxies

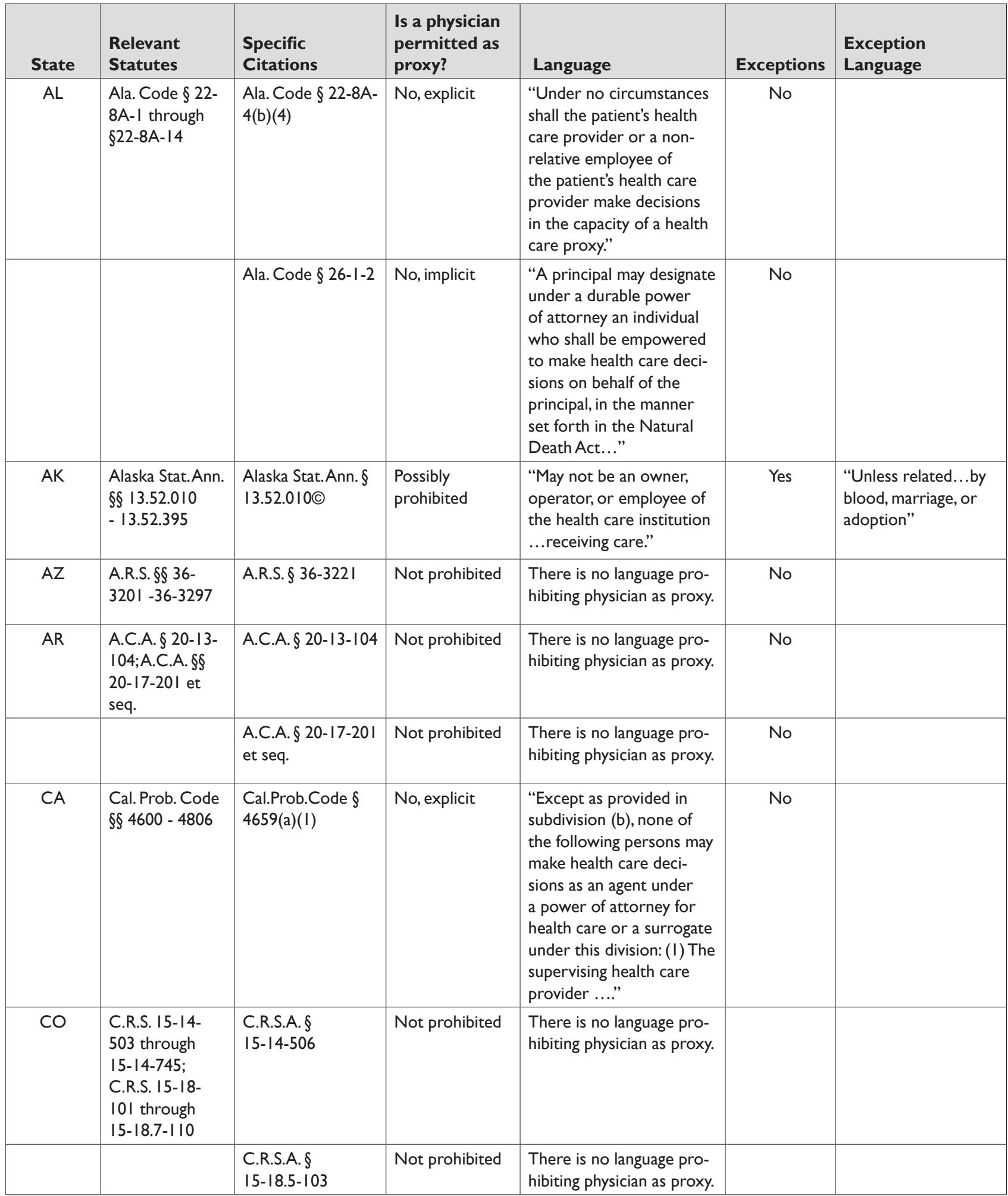




\begin{tabular}{|c|c|c|c|c|c|c|}
\hline State & $\begin{array}{l}\text { Relevant } \\
\text { Statutes }\end{array}$ & $\begin{array}{l}\text { Specific } \\
\text { Citations }\end{array}$ & $\begin{array}{l}\text { Is a physician } \\
\text { permitted as } \\
\text { proxy? }\end{array}$ & Language & Exceptions & $\begin{array}{l}\text { Exception } \\
\text { Language }\end{array}$ \\
\hline CT & $\begin{array}{l}\text { Conn. Gen. } \\
\text { Stat. } \S \S 19 \mathrm{a}- \\
570 \text { through } \\
19 \mathrm{a}-580 \mathrm{~g}\end{array}$ & $\begin{array}{l}\text { C.G.S.A. } \S \\
19 a-576(e)\end{array}$ & No, explicit & $\begin{array}{l}\text { "(e) A physician shall not } \\
\text { act as both health care } \\
\text { representative for a prin- } \\
\text { cipal and attending physi- } \\
\text { cian for the principal." }\end{array}$ & No & \\
\hline $\mathrm{DE}$ & $\begin{array}{l}\text { I6 Del. C. } \S \\
2501 \text { through } \\
16 \text { Del.C. } \S \\
2518\end{array}$ & I6 Del.C. § 2503 & $\begin{array}{l}\text { Possibly } \\
\text { prohibited }\end{array}$ & $\begin{array}{l}\text { "....an agent may not have } \\
\text { a controlling interest in } \\
\text { or be an operator or } \\
\text { employee of a residential } \\
\text { long-term health-care } \\
\text { institution at which the } \\
\text { principal is receiving care." }\end{array}$ & Yes & $\begin{array}{l}\text { "Unless related } \\
\text { to the principal by } \\
\text { blood, marriage or } \\
\text { adoption..." }\end{array}$ \\
\hline DC & $\begin{array}{l}\text { D.C. Code } \\
\S \S 21-2201 \\
\text { through } \\
21-2213\end{array}$ & $\begin{array}{l}\text { D.C. Code } \S \\
21-2209\end{array}$ & No, explicit & $\begin{array}{l}\text { "After an individual has } \\
\text { spent at least } 48 \text { hours } \\
\text { in a health care facility, a } \\
\text { health care provider may } \\
\text { request the individual to } \\
\text { execute a durable power } \\
\text { of attorney for health care } \\
\text { subject to the limitations } \\
\text { set forth in this chapter. } \\
\text { The health care provider } \\
\text { may not be named as the } \\
\text { attorney in fact." }\end{array}$ & & \\
\hline $\mathrm{FL}$ & $\begin{array}{l}\text { Fla. Stat. } \S \\
709.2104 ; \text { Fla. } \\
\text { Stat. } § \S 765.101 \\
\text { through } 765.404\end{array}$ & & Not prohibited & $\begin{array}{l}\text { There is no language pro- } \\
\text { hibiting physician as proxy. }\end{array}$ & & \\
\hline GA & $\begin{array}{l}\text { O.C.G.A. } \S 331- \\
32-I \text { through } \\
3 I-32-14\end{array}$ & $\begin{array}{l}\text { Ga. Code Ann. } \S \\
31-32-4\end{array}$ & No, explicit & $\begin{array}{l}\text { "A physician or health } \\
\text { care provider who is } \\
\text { directly involved in your } \\
\text { health care may not serve } \\
\text { as your health care agent." }\end{array}$ & No & \\
\hline \multirow[t]{2}{*}{$\mathrm{HI}$} & $\begin{array}{l}\text { HRS } \S \S 327 E-I \\
\text { through } \\
327 E-16\end{array}$ & HRS $\S 327 E-3$ & $\begin{array}{l}\text { Possibly } \\
\text { prohibited }\end{array}$ & $\begin{array}{l}\text { "...an agent may not be an } \\
\text { owner, operator, or em- } \\
\text { ployee of the health-care } \\
\text { institution at which the } \\
\text { principal is receiving care." }\end{array}$ & Yes & $\begin{array}{l}\text { "Unless related } \\
\text { to the principal by } \\
\text { blood, marriage, or } \\
\text { adoption..." }\end{array}$ \\
\hline & $\begin{array}{l}\text { HRS } \S 55 \mathrm{le}-\mathrm{I} \\
\text { et seq. }\end{array}$ & & Not prohibited & $\begin{array}{l}\text { There is no language pro- } \\
\text { hibiting physician as proxy. }\end{array}$ & & \\
\hline ID & $\begin{array}{l}\text { Idaho Code } \\
\S \S 39-4509 \\
\text { through } \\
39-45 \text { I5 }\end{array}$ & $\begin{array}{l}\text { Idaho Code } \S \\
39-4510\end{array}$ & No, explicit & $\begin{array}{l}\text { "None of the following } \\
\text { may be designated as your } \\
\text { agent: (I) your treating } \\
\text { health care provider..." }\end{array}$ & No & \\
\hline
\end{tabular}




\begin{tabular}{|c|c|c|c|c|c|c|}
\hline State & $\begin{array}{l}\text { Relevant } \\
\text { Statutes }\end{array}$ & $\begin{array}{l}\text { Specific } \\
\text { Citations }\end{array}$ & $\begin{array}{l}\text { Is a physician } \\
\text { permitted as } \\
\text { proxy? }\end{array}$ & Language & Exceptions & $\begin{array}{l}\text { Exception } \\
\text { Language }\end{array}$ \\
\hline IL & $\begin{array}{l}755 \text { ILCS } 45 / 4-\text { I } \\
\text { through } 755 \\
\text { ILCS } 45 / 4-12\end{array}$ & $\begin{array}{l}755 \text { III. Comp. Stat. } \\
\S 45 / 4-5\end{array}$ & No, explicit & $\begin{array}{l}\text { "Neither the attending } \\
\text { physician nor any other } \\
\text { health care provider may } \\
\text { act as agent under a health } \\
\text { care agency..." }\end{array}$ & Yes & $\begin{array}{l}\text { "...however, a person } \\
\text { who is not adminis- } \\
\text { tering health care to } \\
\text { the patient may act } \\
\text { as health care agent } \\
\text { for the patient even } \\
\text { though the person is a } \\
\text { physician or otherwise } \\
\text { licensed, certified, au- } \\
\text { thorized, or permitted } \\
\text { by law to administer } \\
\text { health care in the or- } \\
\text { dinary course of busi- } \\
\text { ness or the practice of } \\
\text { a profession." }\end{array}$ \\
\hline IN & $\begin{array}{l}\text { Burns Ind. Code } \\
\text { Ann. } \$ \$ 16-36- \\
\text { I.7-0.5 through } \\
\text { I6-36-I.7-5 }\end{array}$ & IC I6-36-I-7 & Not prohibited & $\begin{array}{l}\text { There is no language pro- } \\
\text { hibiting physician as proxy. }\end{array}$ & & \\
\hline IA & $\begin{array}{l}\text { lowa Code } \$ \S \\
\text { I44A.I through } \\
\text { I44B. } 12\end{array}$ & $\begin{array}{l}\text { lowa Code Ann. } \S \\
\text { I44B.4.I }\end{array}$ & No, explicit & $\begin{array}{l}\text { "The following individuals } \\
\text { shall not be designated } \\
\text { as the attorney in fact to } \\
\text { make health care decisions } \\
\text { under a durable power of } \\
\text { attorney for health care: } \\
\text { I.A health care provider } \\
\text { attending the principal on } \\
\text { the date of execution...." }\end{array}$ & No & \\
\hline $\mathrm{KS}$ & $\begin{array}{l}\text { K.S.A. } \$ \S 58-625 \\
\text { through 58-632 }\end{array}$ & $\begin{array}{l}\text { Kan. Stat.Ann. } \S \\
58-629(d)\end{array}$ & No, explicit & $\begin{array}{l}\text { "Neither the treating } \\
\text { health care provider, ... } \\
\text { nor an employee of the } \\
\text { treating health care pro- } \\
\text { vider, nor an employee, } \\
\text { owner, director or officer } \\
\text { of a facility described [in] } \\
\text { subsection (a)( } 2 \text { ) in K.S.A. } \\
58-629 \text { may be designated } \\
\text { as the agent to make } \\
\text { health care decisions } \\
\text { under a durable power of } \\
\text { attorney for health care } \\
\text { decisions..." }\end{array}$ & Yes & $\begin{array}{l}\text { "Unless: } \\
\text { (I) Related to the } \\
\text { principal by blood, } \\
\text { marriage or adop- } \\
\text { tion; or } \\
\text { (2) the principal and } \\
\text { agent are members } \\
\text { of the same commu- } \\
\text { nity of persons who } \\
\text { are bound by vows } \\
\text { to a religious life and } \\
\text { who conduct or as- } \\
\text { sist in the conduct of } \\
\text { religious services and } \\
\text { actually and regularly } \\
\text { engage in religious, } \\
\text { benevolent, charitable } \\
\text { or educational minis- } \\
\text { trations or the per- } \\
\text { formance of health } \\
\text { care services." }\end{array}$ \\
\hline KY & $\begin{array}{l}\text { KRS } \$ \S 311.621 \\
\text { through } 311.643\end{array}$ & $\begin{array}{l}\text { Ky. Rev. Stat. Ann. } \\
\S 3 \text { I I.625(4); } 2013 \\
\text { Kentucky Laws Ch. } \\
\text { I } 27 \text { (HB 385) }\end{array}$ & $\begin{array}{l}\text { Possibly } \\
\text { prohibited }\end{array}$ & $\begin{array}{l}\text { "An employee, owner, } \\
\text { director, or officer of a } \\
\text { health care facility where } \\
\text { the grantor is a resident } \\
\text { or patient shall not be } \\
\text { designated or act as } \\
\text { surrogate..." }\end{array}$ & Yes & $\begin{array}{l}\text { "...unless related to } \\
\text { the grantor within } \\
\text { the fourth degree of } \\
\text { consanguinity or af- } \\
\text { finity or a member of } \\
\text { the same religious or } \\
\text { fraternal order." }\end{array}$ \\
\hline
\end{tabular}




\begin{tabular}{|c|c|c|c|c|c|c|}
\hline State & $\begin{array}{l}\text { Relevant } \\
\text { Statutes }\end{array}$ & $\begin{array}{l}\text { Specific } \\
\text { Citations }\end{array}$ & $\begin{array}{l}\text { Is a physician } \\
\text { permitted as } \\
\text { proxy? }\end{array}$ & Language & Exceptions & $\begin{array}{l}\text { Exception } \\
\text { Language }\end{array}$ \\
\hline LA & $\begin{array}{l}\text { La. Rev. Stat. } \\
\text { Ann. } \$ 28: 233 \\
\text { (Mental health } \\
\text { advance direc- } \\
\text { tives only) }\end{array}$ & $\begin{array}{l}\text { La. Rev. Stat.Ann. } \S \\
28: 233\end{array}$ & No, explicit & $\begin{array}{l}\text { "The following individuals } \\
\text { shall be prohibited from } \\
\text { serving as a representa- } \\
\text { tive: } \\
\text { (I) The treating physician, } \\
\text { provider, or an employee } \\
\text { of the physician or pro- } \\
\text { vider if the physician, } \\
\text { provider, or employee is } \\
\text { unrelated to the principal } \\
\text { by blood, marriage, or } \\
\text { adoption." }\end{array}$ & & \\
\hline ME & $\begin{array}{l}\text { I8-A M.R.S. } \\
\text { 5-80I through } \\
\text { I8-A M.R.S. } \$ \\
\text { 5-8I8 }\end{array}$ & $\begin{array}{l}\text { I8-A M.R.S.A. } \S \\
5-802\end{array}$ & $\begin{array}{l}\text { Possibly } \\
\text { prohibited }\end{array}$ & $\begin{array}{l}\text { "...an agent may not be } \\
\text { an owner, operator or } \\
\text { employee of a residential } \\
\text { long-term health-care } \\
\text { institution at which the } \\
\text { principal is receiving care." }\end{array}$ & Yes & $\begin{array}{l}\text { "Unless related } \\
\text { to the principal by } \\
\text { blood, marriage or } \\
\text { adoption..." }\end{array}$ \\
\hline MD & $\begin{array}{l}\text { Md. HEALTH- } \\
\text { GENERAL } \\
\text { Code Ann. } \S \S \\
5-60 \text { I through } \\
5-626\end{array}$ & $\begin{array}{l}\text { Md. Code Ann., } \\
\text { Health } \S 5-602(b) \\
\text { (I)(i), (ii) (West) }\end{array}$ & $\begin{array}{l}\text { Possibly } \\
\text { prohibited }\end{array}$ & $\begin{array}{l}\text { "Disqualified person de- } \\
\text { fined } \\
\text { (b)(I) In this subsection, } \\
\text { "disqualified person" } \\
\text { means: } \\
\text { (i) An owner, operator, or } \\
\text { employee of a health care } \\
\text { facility from which the de- } \\
\text { clarant is receiving health } \\
\text { care;..." }\end{array}$ & & \\
\hline MA & $\begin{array}{l}\text { ALM GL ch. } \\
20 I D, \S \text { I } \\
\text { through ch. } \\
20 I D, \S I 7\end{array}$ & $\begin{array}{l}\text { Mass. Gen. Laws } \\
\text { Ann. ch. 20ID, } \S 3\end{array}$ & $\begin{array}{l}\text { Possibly } \\
\text { prohibited }\end{array}$ & $\begin{array}{l}\text { "No person who is an } \\
\text { operator, administrator } \\
\text { or employee of a facil- } \\
\text { ity may be appointed as } \\
\text { health care agent by an } \\
\text { adult, who, at the time of } \\
\text { executing the health care } \\
\text { proxy is a patient or resi- } \\
\text { dent of such facility or has } \\
\text { applied for admission to } \\
\text { such facility..." }\end{array}$ & Yes & $\begin{array}{l}\text { "....unless said opera- } \\
\text { tor, administrator or } \\
\text { employee is related } \\
\text { to the principal by } \\
\text { blood, marriage or } \\
\text { adoption." }\end{array}$ \\
\hline $\mathrm{MI}$ & $\begin{array}{l}\text { MCLS } \S \S \\
700.5506 \\
\text { through } \\
700.5520\end{array}$ & & Not prohibited & $\begin{array}{l}\text { There is no language that } \\
\text { prohibits a physician as } \\
\text { proxy. }\end{array}$ & & \\
\hline
\end{tabular}




\begin{tabular}{|c|c|c|c|c|c|c|}
\hline State & $\begin{array}{l}\text { Relevant } \\
\text { Statutes }\end{array}$ & $\begin{array}{l}\text { Specific } \\
\text { Citations }\end{array}$ & $\begin{array}{l}\text { Is a physician } \\
\text { permitted as } \\
\text { proxy? }\end{array}$ & Language & Exceptions & $\begin{array}{l}\text { Exception } \\
\text { Language }\end{array}$ \\
\hline $\mathrm{MN}$ & $\begin{array}{l}\text { Minn. Stat. } \$ \S \\
\text { I45B.0I through } \\
\text { I45C.16 }\end{array}$ & $\begin{array}{l}\text { Minn. Stat.Ann. } \S \\
\text { I45C.03(2)(b)(I) }\end{array}$ & No, explicit & $\begin{array}{l}\text { "(b) The following indi- } \\
\text { viduals are not eligible } \\
\text { to act as the health care } \\
\text { agent, unless the individual } \\
\text { appointed is related to the } \\
\text { principal by blood, mar- } \\
\text { riage, registered domestic } \\
\text { partnership, or adoption, } \\
\text { or unless the principal has } \\
\text { otherwise specified in the } \\
\text { health care directive: } \\
\text { (I) a health care provider } \\
\text { attending the principal on } \\
\text { the date of execution of } \\
\text { the health care directive } \\
\text { or on the date the health } \\
\text { care agent must make de- } \\
\text { cisions for the principal;..." }\end{array}$ & Yes & $\begin{array}{l}\text { "(b) The following } \\
\text { individuals are not } \\
\text { eligible to act as the } \\
\text { health care agent, } \\
\text { unless the individual } \\
\text { appointed is related } \\
\text { to the principal by } \\
\text { blood, marriage, } \\
\text { registered domes- } \\
\text { tic partnership, or } \\
\text { adoption, or unless } \\
\text { the principal has } \\
\text { otherwise specified } \\
\text { in the health care } \\
\text { directive...” }\end{array}$ \\
\hline MS & $\begin{array}{l}\text { Miss. Code } \\
\text { Ann. } \$ \oint 4 I-4 I- \\
20 I \text { through } \\
4 I-4 I-229\end{array}$ & $\begin{array}{l}\text { Miss. Code Ann. } \\
\S 4 \text { I-4I-205 (2) } \\
\text { (West) }\end{array}$ & $\begin{array}{l}\text { Possibly } \\
\text { prohibited }\end{array}$ & $\begin{array}{l}\text { "Unless related to the } \\
\text { principal by blood, mar- } \\
\text { riage, or adoption, an } \\
\text { agent may not be an } \\
\text { owner, operator, or em- } \\
\text { ployee of a residential } \\
\text { long-term health-care } \\
\text { institution at which the } \\
\text { principal is receiving care." }\end{array}$ & Yes & $\begin{array}{l}\text { Unless related to the } \\
\text { principal by blood, } \\
\text { marriage, or adop- } \\
\text { tion, an agent may } \\
\text { not be an owner, op- } \\
\text { erator, or employee } \\
\text { of a residential long- } \\
\text { term health-care in- } \\
\text { stitution at which the } \\
\text { principal is receiving } \\
\text { care. }\end{array}$ \\
\hline $\mathrm{MO}$ & $\begin{array}{l}\S \S 404.800 \\
\text { through } 404.872 \\
\text { R.S.Mo. }\end{array}$ & $\begin{array}{l}\text { Mo.Ann. Stat. } \S \\
404.815\end{array}$ & No, explicit & $\begin{array}{l}\text { "Notwithstanding any } \\
\text { other provision of law to } \\
\text { the contrary, an attending } \\
\text { physician or an employee } \\
\text { of the attending physician, } \\
\text { or an owner, operator } \\
\text { or employee of a health } \\
\text { care facility in which the } \\
\text { patient is a resident, shall } \\
\text { not serve as an attorney } \\
\text { in fact ..." }\end{array}$ & Yes & $\begin{array}{l}\text { "unless: } \\
\text { (I) The patient and } \\
\text { attorney in fact are } \\
\text { related by affinity or } \\
\text { consanguinity within } \\
\text { the second degree; } \\
\text { (2) The patient and } \\
\text { attorney in fact are } \\
\text { members of the same } \\
\text { community of per- } \\
\text { sons who are bound } \\
\text { by vows to a religious } \\
\text { life and who conduct } \\
\text { or assist in the con- } \\
\text { ducting of religious } \\
\text { services and actually } \\
\text { and regularly engage } \\
\text { in religious, benevo- } \\
\text { lent, charitable, or ed- } \\
\text { ucational ministry, or } \\
\text { the performance of } \\
\text { health care services." }\end{array}$ \\
\hline
\end{tabular}




\begin{tabular}{|c|c|c|c|c|c|c|}
\hline State & $\begin{array}{l}\text { Relevant } \\
\text { Statutes }\end{array}$ & $\begin{array}{l}\text { Specific } \\
\text { Citations }\end{array}$ & $\begin{array}{l}\text { Is a physician } \\
\text { permitted as } \\
\text { proxy? }\end{array}$ & Language & Exceptions & $\begin{array}{l}\text { Exception } \\
\text { Language }\end{array}$ \\
\hline MT & $\begin{array}{l}\text { Mont. Code } \\
\text { Anno., } \$ 550- \\
9-101 \text { through } \\
50-10-107\end{array}$ & & Not prohibited & $\begin{array}{l}\text { There is no language pro- } \\
\text { hibiting physician as proxy. }\end{array}$ & & \\
\hline NE & $\begin{array}{l}\text { R.R.S. Neb. } \\
\S \S 30-340 \text { I } \\
\text { through } \\
30-3432\end{array}$ & $\begin{array}{l}\text { Neb. Rev. Stat. } \S \\
30-3406(I)\end{array}$ & No, explicit & $\begin{array}{l}\text { "None of the following } \\
\text { may serve as an attorney } \\
\text { in fact: } \\
\text { (I) The attending } \\
\text { physician;..." }\end{array}$ & No & \\
\hline NV & $\begin{array}{l}\text { Nev. Rev. } \\
\text { Stat.Ann. } \S \S \\
\text { I62A. } 700 \\
\text { through } \\
\text { I62A.860 }\end{array}$ & $\begin{array}{l}\text { Nev. Rev. Stat.Ann. } \\
\S \text { I62A.840 }\end{array}$ & No, explicit & $\begin{array}{l}\text { "I. Except as otherwise } \\
\text { provided in subsection 2, a } \\
\text { principal may not name as } \\
\text { agent in a power of attor- } \\
\text { ney for health care: } \\
\text { (a) His or her provider of } \\
\text { health care; } \\
\text { (b) An employee of his } \\
\text { or her provider of health } \\
\text { care; } \\
\text { (c) An operator of a } \\
\text { health care facility; or } \\
\text { (d) An employee of a } \\
\text { health care facility." }\end{array}$ & Yes & $\begin{array}{l}\text { "2.A principal may } \\
\text { name as agent any } \\
\text { person identified in } \\
\text { subsection I if that } \\
\text { person is the spouse, } \\
\text { legal guardian or } \\
\text { next of kin of the } \\
\text { principal." }\end{array}$ \\
\hline $\mathrm{NH}$ & $\begin{array}{l}\text { RSA I37- } \\
\text { J:I through } \\
\text { | 37-J:33 }\end{array}$ & $\begin{array}{l}\text { N.H. Rev. Stat.Ann. } \\
\S \text { I37-J:8 }\end{array}$ & No, explicit & $\begin{array}{l}\text { "A person may not exer- } \\
\text { cise the authority of agent } \\
\text { while serving in one of the } \\
\text { following capacities: } \\
\text { I.The principal's health } \\
\text { care provider or residen- } \\
\text { tial care provider." }\end{array}$ & No & \\
\hline NJ & $\begin{array}{l}\text { N.J. Stat. } \S \S \\
26: 2 \mathrm{H}-53 \\
\text { through } \\
26: 2 \mathrm{H}-78\end{array}$ & $\begin{array}{l}\text { N.J.Stat.Ann. } \S \\
26: 2 \mathrm{H}-58(\mathrm{a})(2)\end{array}$ & $\begin{array}{l}\text { Possibly } \\
\text { prohibited }\end{array}$ & $\begin{array}{l}\text { "( } 2 \text { An operator, admin- } \\
\text { istrator or employee of } \\
\text { a health care institution } \\
\text { in which the declarant } \\
\text { is a patient or resident } \\
\text { shall not serve as the } \\
\text { declarant's health care } \\
\text { representative unless the } \\
\text { operator, administrator } \\
\text { or employee is related to } \\
\text { the declarant by blood, } \\
\text { marriage, domestic part- } \\
\text { nership, civil union or } \\
\text { adoption." }\end{array}$ & Yes & $\begin{array}{l}\text { "This restriction does } \\
\text { not apply to a physi- } \\
\text { cian, if the physician } \\
\text { does not serve as } \\
\text { the patient's attend- } \\
\text { ing physician and the } \\
\text { patient's health care } \\
\text { representative at the } \\
\text { same time." }\end{array}$ \\
\hline NM & $\begin{array}{l}\text { N.M. Stat. } \\
\text { Ann. } \$ \S 24- \\
7 A-I \text { through } \\
24-7 A-18\end{array}$ & $\begin{array}{l}\text { N.M. Stat.Ann. } \$ \\
24-7 A-2\end{array}$ & $\begin{array}{l}\text { Possibly } \\
\text { prohibited }\end{array}$ & $\begin{array}{l}\text { "...an agent may not be } \\
\text { an owner, operator or } \\
\text { employee of a health-care } \\
\text { institution at which the } \\
\text { principal is receiving care." }\end{array}$ & Yes & $\begin{array}{l}\text { "Unless related } \\
\text { to the principal by } \\
\text { blood, marriage or } \\
\text { adoption..." }\end{array}$ \\
\hline
\end{tabular}




\begin{tabular}{|c|c|c|c|c|c|c|}
\hline State & $\begin{array}{l}\text { Relevant } \\
\text { Statutes }\end{array}$ & $\begin{array}{l}\text { Specific } \\
\text { Citations }\end{array}$ & $\begin{array}{l}\text { Is a physician } \\
\text { permitted as } \\
\text { proxy? }\end{array}$ & Language & Exceptions & $\begin{array}{l}\text { Exception } \\
\text { Language }\end{array}$ \\
\hline NY & $\begin{array}{l}\text { NY CLS Pub } \\
\text { Health } \$ \S 2980 \\
\text { through 2994-u }\end{array}$ & $\begin{array}{l}\text { N.Y. Pub. Health } \\
\text { Law } \S 298 \mathrm{I}(3)\end{array}$ & No, explicit & $\begin{array}{l}\text { "If a physician is appointed } \\
\text { agent, the physician shall } \\
\text { not act as the patient's at- } \\
\text { tending physician after the } \\
\text { authority under the health } \\
\text { care proxy commences, } \\
\text { unless the physician de- } \\
\text { clines the appointment as } \\
\text { agent at or before such } \\
\text { time." }\end{array}$ & No & \\
\hline NC & $\begin{array}{l}\text { N.C. Gen. Stat. } \\
\S \S 32 \mathrm{~A}-15 \\
\text { through 32A-27 }\end{array}$ & $\begin{array}{l}\text { N.C. Gen. Stat. } \S \\
32 \mathrm{~A}-18\end{array}$ & No, explicit & $\begin{array}{l}\text { "Any competent person } \\
\text { who is not engaged in } \\
\text { providing health care to } \\
\text { the principal for remuner- } \\
\text { ation, and who is } 18 \text { years } \\
\text { of age or older, may act as } \\
\text { a health care agent." }\end{array}$ & No & \\
\hline ND & $\begin{array}{l}\text { N.D. Cent. } \\
\text { Code, } \$ \$ 23- \\
06.5-01 \text { through } \\
23-06.5-19\end{array}$ & $\begin{array}{l}\text { N.D. Cent. Code } \S \\
23-06.5-04.1\end{array}$ & No, explicit & $\begin{array}{l}\text { "A person may not exer- } \\
\text { cise the authority of agent } \\
\text { while serving in one of the } \\
\text { following capacities: } \\
\text { I.The principal's health } \\
\text { care provider..." }\end{array}$ & No & \\
\hline $\mathrm{OH}$ & $\begin{array}{l}\text { ORC Ann. } \\
\text { I337. I I through } \\
1337.17\end{array}$ & $\begin{array}{l}\text { Ohio Rev. Code } \\
\text { Ann. } § \quad 1337.12(\mathrm{~A}) \\
(2)\end{array}$ & No, explicit & $\begin{array}{l}\text { "The attending physician } \\
\text { of the principal and an } \\
\text { administrator of any nurs- } \\
\text { ing home in which the } \\
\text { principal is receiving care } \\
\text { shall not be designated } \\
\text { as an attorney in fact in, } \\
\text { or act as an attorney in } \\
\text { fact pursuant to, a durable } \\
\text { power of attorney for } \\
\text { health care." }\end{array}$ & No & \\
\hline OK & $\begin{array}{l}\text { 43A Okl.St. } \S \\
\text { I।- I0 I through } \\
43 \mathrm{~A} \text { Okl.St. } \S \\
\text { I I- I I3 }\end{array}$ & & Not prohibited & $\begin{array}{l}\text { There is no language } \\
\text { prohibiting a physician as } \\
\text { proxy. }\end{array}$ & & \\
\hline OR & $\begin{array}{l}\text { ORS } \$ \S 127.505 \\
\text { through } 127.995\end{array}$ & $\begin{array}{l}\text { Or. Rev. Stat. } \S \\
127.520(1)\end{array}$ & Not prohibited & $\begin{array}{l}\text { "(I) Except as provided in } \\
\text { ORS I } 27.635 \text { or as may } \\
\text { be allowed by court order, } \\
\text { the following persons may } \\
\text { not serve as health care } \\
\text { representatives: } \\
\text { (a) If unrelated to the } \\
\text { principal by blood, mar- } \\
\text { riage or adoption: } \\
\text { (A) The attending physi- } \\
\text { cian or an employee of } \\
\text { the attending physician” }\end{array}$ & Yes & $\begin{array}{l}\text { “(I) Except as pro- } \\
\text { vided in ORS I } 27.635 \\
\text { or as may be allowed } \\
\text { by court order, the } \\
\text { following persons } \\
\text { may not serve as } \\
\text { health care represen- } \\
\text { tatives: } \\
\text { (a) If unrelated to the } \\
\text { principal by blood, } \\
\text { marriage or adoption: } \\
\text { (A) The attending } \\
\text { physician or an em- } \\
\text { ployee of the attend- } \\
\text { ing physician” }\end{array}$ \\
\hline
\end{tabular}




\begin{tabular}{|c|c|c|c|c|c|c|}
\hline State & $\begin{array}{l}\text { Relevant } \\
\text { Statutes }\end{array}$ & $\begin{array}{l}\text { Specific } \\
\text { Citations }\end{array}$ & $\begin{array}{l}\text { Is a physician } \\
\text { permitted as } \\
\text { proxy? }\end{array}$ & Language & Exceptions & $\begin{array}{l}\text { Exception } \\
\text { Language }\end{array}$ \\
\hline PA & $\begin{array}{l}20 \text { Pa.C.S.A. } \S \\
545 \text { I through } \\
20 \text { Pa.C.S.A. } \S \\
5465\end{array}$ & $\begin{array}{l}20 \text { PA. Cons. Stat. } \\
\text { Ann. } \$ 5455 \text { (West } \\
\text { 20I2) }\end{array}$ & No, explicit & $\begin{array}{l}\text { "...a health care agent of } \\
\text { the principal may not be } \\
\text { any of the following: } \\
\text { (I) The principal's attend- } \\
\text { ing physician or other } \\
\text { health care provider." }\end{array}$ & Yes & $\begin{array}{l}\text { "Unless related } \\
\text { to the principal by } \\
\text { blood, marriage or } \\
\text { adoption..." }\end{array}$ \\
\hline RI & $\begin{array}{l}\text { R.I. Gen. Laws } \\
\S \S 23-4.10-1 \\
\text { through } \\
23-4.11-15\end{array}$ & $\begin{array}{l}\text { R.I. Gen. Laws } \S \\
23-4.10-2\end{array}$ & No, explicit & $\begin{array}{l}\text { "None of the following } \\
\text { may be designated as your } \\
\text { agent: }(I) \text { your treating } \\
\text { health care provider,..." }\end{array}$ & No & \\
\hline SC & $\begin{array}{l}\text { S.C. Code } \\
\text { Ann. } \S \S 62-5- \\
504 \text { through } \\
62-5-505\end{array}$ & $\begin{array}{l}\text { S.C. Code Ann. } \S \\
62-5-504(C)(I)(d)\end{array}$ & No, explicit & $\begin{array}{l}\text { "A health care agent may } \\
\text { not be a health care pro- } \\
\text { vider, or an employee of a } \\
\text { provider, with whom the } \\
\text { principal has a provider- } \\
\text { patient relationship at } \\
\text { the time the health care } \\
\text { power of attorney is ex- } \\
\text { ecuted, or an employee } \\
\text { of a nursing care facility } \\
\text { in which the principal } \\
\text { resides, or a spouse of the } \\
\text { health care provider..." }\end{array}$ & Yes & $\begin{array}{l}\text { "...unless the health } \\
\text { care provider, em- } \\
\text { ployee, or spouse } \\
\text { is a relative of the } \\
\text { principal." }\end{array}$ \\
\hline SD & $\begin{array}{l}\text { S.D. Codified } \\
\text { Laws } \$ \oint 34-12 C- \\
\text { I; S.D. Codified } \\
\text { Laws } \S \S 59-7- \\
\text { 2.I through } \\
59-7-2.8\end{array}$ & $\begin{array}{l}\text { S.D. Codified } \\
\text { Laws } \S 59-7-2.1\end{array}$ & Not prohibited & $\begin{array}{l}\text { There is no language } \\
\text { prohibiting a physician as } \\
\text { proxy }\end{array}$ & & \\
\hline $\mathrm{TN}$ & $\begin{array}{l}\text { Tenn. Code } \\
\text { Ann. } \S \S 34-6- \\
201 \text { through } \\
34-6-218\end{array}$ & $\begin{array}{l}\text { Tenn. Code Ann. } \S \\
\text { 34-6-203(b)(I) }\end{array}$ & No, explicit & $\begin{array}{l}\text { "Neither the treating } \\
\text { health care provider nor } \\
\text { an employee of the treat- } \\
\text { ing health care provider, } \\
\text { nor an operator of a } \\
\text { treating health care insti- } \\
\text { tution nor an employee of } \\
\text { an operator of a treating } \\
\text { health care institution } \\
\text { may be designated as the } \\
\text { attorney in fact to make } \\
\text { health care decisions } \\
\text { under a durable power of } \\
\text { attorney for health care; } \\
\text { and } \\
\text { (2) A health care provider } \\
\text { or employee of a health } \\
\text { care provider may not } \\
\text { act as an attorney in fact } \\
\text { to make health care deci- } \\
\text { sions if the health care } \\
\text { provider becomes the } \\
\text { principal's treating health } \\
\text { care provider." }\end{array}$ & Yes & $\begin{array}{l}\text { "An employee of } \\
\text { the treating health } \\
\text { care provider or an } \\
\text { employee of an op- } \\
\text { erator of a treating } \\
\text { health care institution } \\
\text { may be designated } \\
\text { as the attorney in } \\
\text { fact to make health } \\
\text { care decisions under } \\
\text { a durable power of } \\
\text { attorney for health } \\
\text { care if: } \\
\text { ( } 1 \text { ) The employee so } \\
\text { designated is a rela- } \\
\text { tive of the principal } \\
\text { by blood, marriage or } \\
\text { adoption; and } \\
\text { (2) The other re- } \\
\text { quirements of this } \\
\text { part are satisfied." }\end{array}$ \\
\hline
\end{tabular}




\begin{tabular}{|c|c|c|c|c|c|c|}
\hline State & $\begin{array}{l}\text { Relevant } \\
\text { Statutes }\end{array}$ & $\begin{array}{l}\text { Specific } \\
\text { Citations }\end{array}$ & $\begin{array}{l}\text { Is a physician } \\
\text { permitted as } \\
\text { proxy? }\end{array}$ & Language & Exceptions & $\begin{array}{l}\text { Exception } \\
\text { Language }\end{array}$ \\
\hline & & $\begin{array}{l}\text { Tenn. Code Ann. } \S \\
68-11 \text {-I806(g)(I) }\end{array}$ & No, explicit & $\begin{array}{l}\text { "(A) Neither the treating } \\
\text { health care provider nor } \\
\text { an employee of the treat- } \\
\text { ing health care provider, } \\
\text { nor an operator of a } \\
\text { health care institution nor } \\
\text { an employee of an opera- } \\
\text { tor of a health care insti- } \\
\text { tution may be designated } \\
\text { as a surrogate; and } \\
\text { (B) A health care pro- } \\
\text { vider or employee of a } \\
\text { health care provider may } \\
\text { not act as a surrogate, if } \\
\text { the health care provider } \\
\text { becomes the principal's } \\
\text { treating health care } \\
\text { provider." }\end{array}$ & Yes & $\begin{array}{l}\text { "An employee of the } \\
\text { treating health care } \\
\text { provider or an em- } \\
\text { ployee of an opera- } \\
\text { tor of a health care } \\
\text { institution may be } \\
\text { designated as a sur- } \\
\text { rogate, if: } \\
\text { (A) The employee so } \\
\text { designated is a rela- } \\
\text { tive of the principal } \\
\text { by blood, marriage, or } \\
\text { adoption; and } \\
\text { (B) The other re- } \\
\text { quirements of this } \\
\text { section are satisfied." }\end{array}$ \\
\hline $\mathrm{TX}$ & & $\begin{array}{l}\text { Tex. Health \& } \\
\text { Safety Code } \S \\
\text { I66.153 }\end{array}$ & No, explicit & $\begin{array}{l}\text { "A person may not exer- } \\
\text { cise the authority of an } \\
\text { agent while the person } \\
\text { serves as: } \\
\text { (I) the principal's health } \\
\text { care provider..." Health \& } \\
\text { Safety Code } \S 166.153\end{array}$ & No & \\
\hline $\mathrm{VT}$ & $\begin{array}{l}\text { I8V.S.A. } \S 9700 \\
\text { through } 18 \\
\text { V.S.A. } \S 9720\end{array}$ & I8V.S.A. § 9702 (c) & No, explicit & $\begin{array}{l}\text { "The principal's health } \\
\text { care provider may not be } \\
\text { the principal's agent." }\end{array}$ & No & \\
\hline VA & $\begin{array}{l}\text { Va. Code } \\
\text { Ann. } \$ \oint 54.1 \text { - } \\
298 \text { I through } \\
54.1-2996\end{array}$ & $\begin{array}{l}\text { Va. Code Ann. } \S \\
\text { 54.1-2983 }\end{array}$ & Not prohibited & & & \\
\hline WA & $\begin{array}{l}\text { West's RCWA } \\
\$ \S 1 \mathrm{I} .94 .010 \\
\text { through } \\
\text { I I.94.90I }\end{array}$ & $\begin{array}{l}\text { West's RCWA } \S \\
\text { I I.94.010(3)(b) }\end{array}$ & No, explicit & $\begin{array}{l}\text { "Unless he or she is the } \\
\text { spouse, state registered } \\
\text { domestic partner, or adult } \\
\text { child or brother or sister } \\
\text { of the principal, none of } \\
\text { the following persons may } \\
\text { act as the attorney-in-fact } \\
\text { for the principal:Any of } \\
\text { the principal's physicians..." }\end{array}$ & Yes & $\begin{array}{l}\text { "Unless he or she } \\
\text { is the spouse, state } \\
\text { registered domestic } \\
\text { partner, or adult child } \\
\text { or brother or sister } \\
\text { of the principal..." }\end{array}$ \\
\hline WV & $\begin{array}{l}\text { W.Va. Code } \$ \S \\
16-30-1 \text { through } \\
16-30-25\end{array}$ & $\begin{array}{l}\text { W.Va. Code } \S 16- \\
30-4(c)(I)\end{array}$ & No, explicit & $\begin{array}{l}\text { “(c) The following per- } \\
\text { sons may not serve as a } \\
\text { medical power of attorney } \\
\text { representative or succes- } \\
\text { sor medical power of at- } \\
\text { torney representative: (I) } \\
\text { A treating health care pro- } \\
\text { vider of the principal...” }\end{array}$ & No & \\
\hline
\end{tabular}




\begin{tabular}{|c|c|c|c|c|c|c|}
\hline State & $\begin{array}{l}\text { Relevant } \\
\text { Statutes }\end{array}$ & $\begin{array}{l}\text { Specific } \\
\text { Citations }\end{array}$ & $\begin{array}{l}\text { Is a physician } \\
\text { permitted as } \\
\text { proxy? }\end{array}$ & Language & Exceptions & $\begin{array}{l}\text { Exception } \\
\text { Language }\end{array}$ \\
\hline WI & $\begin{array}{l}\text { Wis. Stat.Ann. } \S \\
\text { I55.0I through } \\
\text { Wis. Stat.Ann. } § \\
\text { I55.80 }\end{array}$ & $\begin{array}{l}\text { Wis. Stat.Ann. } \S \\
\text { I55.05 (3) }\end{array}$ & No, explicit & $\begin{array}{l}\text { "No health care provider } \\
\text { for an individual, em- } \\
\text { ployee of that health care } \\
\text { provider or employee } \\
\text { of a health care facility } \\
\text { in which an individual is } \\
\text { a patient or resides, or } \\
\text { a spouse of any of those } \\
\text { providers or employees, } \\
\text { may be designated by the } \\
\text { individual as a health care } \\
\text { agent..." }\end{array}$ & Yes & $\begin{array}{l}\text { “... Unless the health } \\
\text { care provider, em- } \\
\text { ployee or spouse of } \\
\text { the provider or em- } \\
\text { ployee is a relative of } \\
\text { the individual.” Wis. } \\
\text { Stat.Ann. } § 155.05(3)\end{array}$ \\
\hline WY & $\begin{array}{l}\text { Wyo. Stat. } \S 35- \\
22-40 \text { I through } \\
35-22-416\end{array}$ & $\begin{array}{l}\text { Wyo. Stat.Ann. } \S \\
\text { 35-22-406(j) }\end{array}$ & $\begin{array}{l}\text { Possibly } \\
\text { prohibited }\end{array}$ & $\begin{array}{l}\text { “...a surrogate may not } \\
\text { be an owner, operator or } \\
\text { employee of a residential } \\
\text { or community care facil- } \\
\text { ity at which the patient is } \\
\text { receiving care..." }\end{array}$ & Yes & $\begin{array}{l}\text { "Unless related to } \\
\text { the patient by blood, } \\
\text { marriage or adop- } \\
\text { tion..." }\end{array}$ \\
\hline
\end{tabular}

This represents a listing of relevant State laws governing who may serve as a HCPOA, current as of February 24, 2015.

Table 2

\section{Six Domains of Possible Concern for Physicians Acting as Surrogate Decision-Makers for Their Patients}

\begin{tabular}{|l|l|}
\hline Areas of Concern & Mechanisms to Address Concern \\
\hline Established relationships & Require relationship between doctor and patient of at least I year \\
\hline Detailed discussions & $\begin{array}{l}\text { Require detailed discussions of patients wishes in medical record (update at least } \\
\text { annually) }\end{array}$ \\
\hline Conflicts of interest & All conceivably relevant conflicts disclosed (and documented in the medical record) \\
\hline Determination of decision-making capacity & $\begin{array}{l}\text { Certification of loss of the patient's decision-making capacity should be performed by } \\
\text { a physician different from the surrogate }\end{array}$ \\
\hline End of life decisions & $\begin{array}{l}\text { Should be carefully discussed with physician colleagues and with the patient in prior } \\
\text { conversations }\end{array}$ \\
\hline Clinical research & $\begin{array}{l}\text { Should be approached cautiously and perhaps only Phase } 3 \text { (therapeutic) clinical trials } \\
\text { in which the physician-proxy has no conflicts }\end{array}$ \\
\hline
\end{tabular}


process as part of their power and interest in regulating safe medical practice.

\section{Acknowledgments}

We would like to thank Professor Doriane L. Coleman of Duke University School of Law for her many helpful comments and criticisms.

\section{References}

1. Schloendorff v. Society of New York Hospital, in N.Y., N.E.. 1914, New York Court of Appeals. at 125, 92; Research, T.N.C.f.t.P.o.H.S.o.B.a.B.; Department of Health, Education, and Welfare, The Belmont Report: Ethical Principles and Guidelines for the Protection of Human Subjects of Research (1979), Washington, D.C.

2. T.M. Pope and T. Sellers, "Legal Briefing: The Unbefriended: Making Healthcare Decisions for Patients without Surrogates (Part 2)," Journal of Clinical Ethics 23, no. 2 (2011): at 177-192.

3. J. T. Berger, E. G. DeRenzo, and J. Schwartz, "Surrogate Decision Making: Reconciling Ethical Theory and Clinical Practice," Annals of Internal Medicine 149, no. 1 (2008): 48-53; L. M. Kopelman, "The Best Interests Standard for Incompetent or Incapacitated Persons of All Ages," Journal of Law, Medicine छ Ethics 35, no. 1 (2007): 187-196.

4. E. J. Emanuel and L. L. Emanuel, "Proxy Decision Making for Incompetent Patients: An Ethical and Empirical Analysis," JAMA 267, no. 15 (1992): 2067-2071; K. A. Bramstedt, "Questioning the Decision-Making Capacity of Surrogates," Internal Medicine Journal 33, nos. 5-6 (2003): at 257-259.

5. W. Meadow et al., "Power and Limitations of Daily Prognostications of Death in the Medical Intensive Care Unit," Critical Care Medicine 39, no. 3 (2011): 474-479; J. D. Lantos, "Not Practicing What We Preach," JAMA Pediatrics 167, no. 10 (2013): 899-900.

6. L. S. Zier et al., "Surrogate Decision Makers' Interpretation of Prognostic Information: A Mixed-Methods Study," Annals of Internal Medicine 156, no. 5 (2012): 360-366.

7. C. Schoen et al., "Access, Affordability, And Insurance Complexity Are Often Worse in the United States Compared to Ten Other Countries," Health Affairs 32, no. 12 (2013): 2205-2215; S. M. Petterson et al., "Projecting US Primary Care Physician Workforce Needs: 2010-2025," Annals of Family Medicine 10, no. 6 (2012): 503-509; S. L. Decker, "In 2011 Nearly OneThird of Physicians Said They Would Not Accept New Medicaid Patients, but Rising Fees May Help," Health Affairs 31, no. 8 (2012): 1673-1679.

8. D. Mechanic and S. Meyer, "Concepts of Trust among Patients with Serious Illness," Social Science Eै Medicine 51, no. 5 (2000): 657-668; D. Mechanic, "In My Chosen Doctor I Trust," BMJ 329, no. 7480 (2004): 1418-1419.

9. R. Street, Jr. and P. Haidet, "How Well Do Doctors Know Their Patients? Factors Affecting Physician Understanding of Patients' Health Beliefs," Journal of General Internal Medicine 26, no. 1 (2011): 21-27.

10. P. G. Black et al., "Can a Patient Designate His Doctor as His Proxy Decision Maker?” Pediatrics 131, no. 5 (2013): 986-990; A. Rai, M. Siegler, and J. Lantos, "The Physician as a Health Care Proxy," Hastings Center Report 29, no. 5 (1999): 14-19.

11. U.S. Census Bureau, "2012 National Population Projections," available at <http://www.census.gov/population/projections/ data/national/2012.html> (last visited November 25, 2015). Also see P. A. Heidenreich et al., "Forecasting the Future of Cardiovascular Disease in the United States: A Policy Statement from the American Heart Association," Circulation 123, no. 8 (2011): 933-944.

12. M. Cooke, "Cost Consciousness in Patient Care - What Is Medical Education's Responsibility?” New England Journal of Medicine 362, no. 14 (2010): 1253-1255; N. S. Ward et al., "Perceptions of Cost Constraints, Resource Limitations, and
Rationing in United States Intensive Care Units: Results of a National Survey," Critical Care Medicine 36, no. 2 (2008): 471-476; ABIM (American Board of Internal Medicine) Foundation, "Medical Professionalism in the New Millennium: A Physician Charter," Annals of Internal Medicine 136, no. 33 (2002): 243-246.

13. M. D. Fox, "Stewards of Public Trust: Responsible Transplantation," American Journal of Bioethics 3, no. 1 (2003): v-vii; A. E. Courtney and A. P. Maxwell, "The Challenge of Doing What Is Right in Renal Transplantation: Balancing Equity and Utility," Nephron Clinical Practice 111, no. 1 (2009). c62-c68.

14. C. A. Moylan et al., "Disparities in Liver Transplantation Before and After Introduction of the MELD Score," JAMA 300, no. 20 (2008): 2371-2378; K. M. Wille et al., "Disparities in Lung Transplantation Before and After Introduction of the Lung Allocation Score," Journal of Heart and Lung Transplantation 32, no. 7 (2013): 684-692.

15. D. Sudarsky et al., "The Impact of Industry Representative's Visits on Utilization of Coronary Stents," American Heart Journal 166, no. 2 (2013): 258-265; J. L. Malin et al., "Medical Oncologists' Perceptions of Financial Incentives in Cancer Care," Journal of Clinical Oncology 31, no. 5 (2013): 530-535. 16. See, for example, M. Angell, "The Case of Helga Wanglie: A New Kind of 'Right to Die' Case," New England Journal of Medicine 325, no. 7 (1991): 511-512, and In re Helga Wanglie, Fourth Judicial District (Dist. Ct. Probate Ct. Div.) PX-91-283. Minnesota, Hennepin County.

17. NCGS \$90-322, available at <http://www.ncga.state.nc.us/ EnactedLegislation/Statutes/HTML/ByArticle/Chapter_90/ Article_23.html > (last visited December 8, 2015).

18. J. M. Luce and D. B. White, "The Pressure to Withhold or Withdraw Life-Sustaining Therapy from Critically Ill Patients in the United States," American Journal of Respiratory and Critical Care Medicine 175, no. 11 (2007): 1104-1108; D. B. White et al., "Decisions to Limit Life-Sustaining Treatment for Critically Ill Patients Who Lack Both Decision-Making Capacity and Surrogate Decision-Makers," Critical Care Medicine 34, no. 8 (2006): 2053-2059; D. B. White et al., "Life Support for Patients without a Surrogate Decision Maker: Who Decides?" Annals of Internal Medicine 147, no. 1 (2007): 34-40; D. B. White, A. Jonsen, and B. Lo, "Ethical Challenge: When Clinicians Act as Surrogates for Unrepresented Patients," American Journal of Critical Care 21, no. 3 (2012): 202-207. One other exception in many jurisdictions is permitting doctors to serve as surrogates for relatives. However, it can be reasonably assumed that these physicians are also not serving simultaneously as the relative's doctor, a practice that is discouraged by both codes of medical ethics (see AMA, "AMA Code of Medical Ethics Opinion 8.19," available at <http://www.ama-assn.org/ ama/pub/physician-resources/medical-ethics/code-medicalethics/opinion819.page> [last visited November 25, 2015]) and state medical licensure boards.

19. Georgia Code Ann § 31-32-4; Kansas Stat. Ann. § 58-629(d).

20. J. E. Perry and R. C. Stone, "In the Business of Dying: Questioning the Commercialization of Hospice," Journal of Law, Medicine $\xi$ Ethics 39, no. 2 (2011): 224-234; L. S. Dalrymple et al., "Comparison of Hospitalization Rates among ForProfit and Nonprofit Dialysis Facilities," Clinical Journal of the American Society of Nephrology 9, no. 1 (2014): 73-81.

21. P. B. Bach, "Reforming the Payment System for Medical Oncologyreforming the Payment System for Medical Oncologyviewpoint," JAMA 310, no. 3 (2013): 261-262; M. Jacobson et al., "Does Reimbursement Influence Chemotherapy Treatment for Cancer Patients?" Health Affairs (Millwood) 25, no. 2 (2006): 437-43; L. E. Schnipper and N. J. Meropol, "Payment for Cancer Care: Time for a New Prescription," Journal of Clinical Oncology 32, no. 36 (2014): 4027-4028; S. L. Goff et al., "How Cardiologists Present the Benefits of Percutaneous Coronary Interventions to Patients with Stable Angina: A Qualitative Analysis," JAMA Internal Medicine 174, no. 10 (2014): 1614-1621. 
22. P. H. Ditto et al., "Advance Directives as Acts of Communication: A Randomized Controlled Trial," Archives of Internal Medicine 161, no. 3 (2001): 421-430; S. M. Moorman, R. M. Hauser, and D. Carr, "Do Older Adults Know Their Spouses' End-of-Life Treatment Preferences?” Research on Aging 31, no. 4 (2009): 463-491; D. I. Shalowitz, E. Garrett-Mayer, and D. Wendler, "The Accuracy of Surrogate Decision Makers: A Systematic Review," Archives of Internal Medicine 166, no. 5 (2006): 493-497; M. J. Silveira, S. Y. H. Kim, and K. M. Langa, "Advance Directives and Outcomes of Surrogate Decision Making before Death," New England Journal of Medicine 362, no. 13 (2010): 1211-1218

23. S. Varma and D. Wendler, "Medical Decision Making for Patients without Surrogates," Archives of Internal Medicine 167, no. 16 (2007): 1711-1715.

24. P. A. Ubel, "Physicians Recommend Different Treatments for Patients Than They Would Choose for Themselves," Archives of Internal Medicine 171, no. 7 (2011): 630-634.

25. M. P. Combs et al., "Substituted Judgment in Principle and Practice: A National Physician Survey," Mayo Clinic Proceedings 88, no. 7 (2013): 666-673.

26. See Street, Jr. and Haidet, supra note 9; J. Bensing, M. Rimondini, and A. Visser, "What Patients Want: Patient Education and Counseling," 90, no. 3 (2013): 287-290; J. Jagosh et al., "The Importance of Physician Listening from the Patients' Perspective: Enhancing Diagnosis, Healing, and the DoctorPatient Relationship," 85, no. 3 (2011): 369-374; W. Levinson and P. A. Pizzo, "Patient-Physican Communication: It's about Time," JAMA 305, no. 17 (2011): 1802-1803.

27. See Institute of Medicine, Dying in America: Improving Quality and Honoring Individual Preferences Near the End of Life (Washington, D.C.: The National Academies Press, 2015).

28. Pew Research Center, "America's Changing Religious Landscape," available at <http://www.pewforum.org/2015/05/12/ americas-changing-religious-landscape/> (last visited November 25, 2015). However, this most recent Pew survey suggests that there has also been a major increase in the percentage of Americans labeling themselves as unaffiliated, although this should not be taken to infer that they are either atheist or agnostic.

29. F. A. Curlin et al., "The Association of Physicians' Religious Characteristics with Their Attitudes and Self-Reported Behaviors Regarding Religion and Spirituality in the Clinical Encoun- ter," Medical Care 44, no. 5 (2006): 446-453; F. A. Curlin et al., "Religion, Conscience, and Controversial Clinical Practices," New England Journal of Medicine 356, no. 6 (2007): 593-600. F. A. Curlin et al., "To Die, to Sleep: US Physicians' Religious and Other Objections to Physician-Assisted Suicide, Terminal Sedation, and Withdrawal of Life Support," American Journal of Hospice and Palliative Medicine 25, no. 2 (2008): 112-120; F. A. Curlin et al., "Physicians' Observations and Interpretations of the Influence of Religion and Spirituality on Health," Archives of Internal Medicine 167, no. 7 (2007): 649-654.

30. M. A. Hall et al., "Measuring Trust in Medical Researchers," Medical Care 44, no. 11 (2006): 1048-1053; K. P. Weinfurt et al., "Disclosing Conflicts of Interest in Clinical Research: Views of Institutional Review Boards, Conflict of Interest Committees, and Investigators," Journal of Law, Medicine छ Ethics 34, no. 3 (2006): 581-591; K. P. Weinfurt et al., "Views of Potential Research Participants on Financial Conflicts of Interest: Barriers and Opportunities for Effective Disclosure," Journal of General Internal Medicine 21, no. 9 (2006): 901-906; K. P. Weinfurt et al., "Disclosure of Financial Relationships to Participants in Clinical Research," Nere England Journal of Medicine 361, no. 9 (2009): 916-921.

31. See White, Jonsen, and Lo, supra note 18.

32. See 45 CFR 46, Subpart D, available at <http://www.hhs. gov/ohrp/humansubjects/guidance/45cfr46.html> (last visited November 25, 2015).

33. J. R. Schroedel and P. Fiber, "Punitive Versus Public Health Oriented Responses to Drug Use by Pregnant Women," Yale Journal of Health Policy, Law, and Ethics 1, no. 1 (2013): 15.

34. R. L. Sudore and T. R. Fried, "Redefining the 'Planning' in Advance Care Planning: Preparing for End-of-Life Decision Making," Annals of Internal Medicine 153, no. 4 (2010): 256U74; D. J. A. Janssen et al., "A Call for High-Quality Advance Care Planning in Outpatients with Severe Copd or Chronic Heart Failure," CHEST Journal 139, no. 5 (2011): 1081-1088; J. W. Mack et al., "Associations between End-of-Life Discussion Characteristics and Care Received Near Death: A Prospective Cohort Study," Journal of Clinical Oncology 30, no. 35 (2012): 4387-4395; E. O. Lee and E. J. Emanuel, "Shared Decision Making to Improve Care and Reduce Costs," Ner England Journal of Medicine 368, no. 1 (2013): 6-8.

35. Dent v. West Virginia, in U.S. 1889, Supreme Court, at 114. 